\title{
Educational Levels and Export Performance of Iranian Industries
}

\author{
Vahid Mehrbani \\ University of Tehran, Tehran, Iran \\ Email:vmehrbani@ut.ac.ir
}

How to cite this paper: Mehrbani, V. (2018) Educational Levels and Export Performance of Iranian Industries. Theoretical Economics Letters, 8, 1460-1474. https://doi.org/10.4236/tel.2018.88094

Received: April 19, 2018

Accepted: June 4, 2018

Published: June 7, 2018

Copyright (C) 2018 by author and Scientific Research Publishing Inc. This work is licensed under the Creative Commons Attribution International License (CC BY 4.0).

http://creativecommons.org/licenses/by/4.0/

\begin{abstract}
This paper examines a composite implication of human capital theory and knowledge-based economy literature with regard to export performance of Iranian industries. It is expected that education particularly in higher levels contributes to the expansion of export. This is the hypothesis that is tested by underlying the Branson's export function and using a panel data of industries with two-digit codes in 2003-2013. Results show that education only in MA (MS) and PhD levels has positive and significant effect on export but lower levels of education have no effect. The coefficients indicate that a 1 percent increase in completion of MA (MS) and $\mathrm{PhD}$ degrees will increase the export of industry by $0.18(0.15)$ percent respectively. It seems that education contributes to export in higher levels but has no important role in lower levels. It is indicated that the results are somewhat in contrast to filter theory proposed by Arrow (1973).
\end{abstract}

\section{Keywords}

Human Capital, Education, Export, Industry

\section{Introduction}

Modern advanced economies are discerned with wide and deep applying knowledge in production of goods and services as well as export sector. This situation is named knowledge-based economy that has made a wave of orientation to knowledge in worldwide exclusively in new-emerged economies. Today, the post-industrial economy is based on knowledge and neglecting this leads to backwardness in economic development. The backbone of this issue is observed in human capital theory that claims education is an investment process which accumulates knowledge as a type of capital. Therefore, every society that establishes better educational system would be more successful in economic perfor- 
mance.

One of the best examples in confirming this claim is the vast economic growth of East Asian countries which is called Asian economic miracle. Between 1960 and 1985, real per capita income in Japan and Four Tigers increased more than four times and more than twice in three south Eastern Asian countries [1]. Different explanations have been presented to descript the reasons of this growth but one of them that is indisputable, impresses on the pivotal role of education [2] [3]. Private domestic investment and rapidly growing human capital were the major engines of growth [1]. Almost in all Asian economies with fast growth, improvement and transformation of educational systems have been dramatic [1].

What explains this process and evidence is endogenous growth models that introduced and developed by Romer [4], Lucas [5], Azariadis and Drazen [6] and Stokey [3]. These pioneers have differently theorized the role of human capital or education in economic growth. The purpose of these studies was to show that education directly is one of the production and growth sources by increasing productivity, whether formal education that is supplied in schools and universities or non-formal education that is provided as on-the-job training in firms. For example, Romer [7] observed the positive effect of education on growth in all market-based economies. Benhabib and Spiegel [8] used a cross section analysis and shown that human capital has no effect on growth of per capita income but has positive impact on growth of total factor productivity. Fleisher et al. [9] studied the role of education in affecting productivity of labor in China. They found that more educated workers had stronger effect on value added than less educated ones. On the contrary, Bils and Klenow [10] found that not only the effect of schooling on economic growth is weak but also the negative effect is strong.

Not to mention the direct effect of education on output, there is another link that describes the role of education in economic expansion which is export. The latter issue has been apparently demonstrated in East Asia. As Stokey [3] outlined, the fast growth of per capita income in most of newly industrialized countries such as East Asia has been accompanied with quick expansion of export volume and rapid growth of education.

Export is one of the most important sectors in any economy because whatever this sector expands, more and newer markets open are opened to the domestic producers and, hence, economic growth would be more achievable. It is claimed that export is more expected to use knowledge inputs than other areas and role of education in this sector is more appeared.

The purpose of this paper is to investigate the role of education in expansion of export in Iran's economy. Methodology of current analysis is a deductive approach. In this line, a top-to-down reasoning is used to describe the nature of relationship between various variables which are of interest, that is, export and human capital forms as educational levels. This procedure leads to hypothesis that must be tested. Afterwards, regression analysis based on Branson's theoret- 
ical model [11] is used to test hypothesis and reaching to empirical evidence. According to evidence, it is attempted to conclude. Nevertheless, the limitation of this study is that it is confined only to industry and does not include the whole of economy. However, the contribution of current study is that the export performance of industries is analyzed with respect to labors with different levels of schooling and, hence, the educational levels are isolated to lead to clear-cut evidence. The hypothesis is that the higher the level of education, the more export of industries. Evidence from a developing economy such as Iran can help to identifying the importance of formal education in real economy. Accordingly, sections of paper are organized as follows. Next section reviews the literature. Third section introduces empirical model with data. The forth includes findings and the fifth concludes.

\section{Literature Review}

Emergence of human capital concept and outcomes of its accumulation at the outset of 1960s by pioneering Schultz [12] and Becker [13] led finally to understanding this issue that capital formation by education is one of the engines of economic growth. What supports to this idea is the positive effect of education on labor productivity [14]. But, why education improves the productive ability of labor? Various types of education enable ones to do particular jobs and activities or enable labor to do the certain work more effectively [15]. The reason of this superior feature of educated persons is that more literate people are more efficient consumers of information [16] because education enhances one's ability in receiving, decoding and understanding information [15]. This is, in effect, a skill that falls to the lot of educated workers and the same as Becker [17] argued, education teaches workers valuable skills that make them more productive.

Human capital approach to allocative efficiency assumes that allocative ability is mostly an acquired skill, not an innate one. This skill is a kind of human capital in the sense that it is acquired at a cost and generates a valuable stream of services in future. It is acquired by schooling and searching for useful information [18]. Since education is a process which accumulates knowledge and, in viewpoint of development analysts, such accumulation of knowledge (human capital) has pivotal role in economic growth [19] and development process [20], we can perceive the importance of education in a developing economy.

Arrow [21] posed the concept of learning-by-doing. The implication of his argument is that an educated person learns more rapid and increases efficiency better and more extensive than an uneducated one. In other side, there is on-the-job training. This type of education makes the capital-saving technological progress in firm. As Feldman noted, ideas are embedded in individuals who have skill, knowledge and know-how to engage in technological advance [22]. Accordingly, putting labor at on-the-job training process can help to technological progress and can lead to producing more outputs by the same inputs in which is equivalent to higher productivity of factors (see for example: Sepúlveda 
[23]).

Undeniable role of education in economic expansion provided a background for analyzing this issue at the micro level and linked this to the performance of firm. Grant conceptualized the firm as an institution for integrating knowledge [24]. Spender proposed the theory of knowledge-based firm and considered it consisting of insights beyond the theory of production function and resource-based firm [25]. Otani defined the firm's entrepreneurial capacity as the knowledge of firm's manager about comprising elements of firm [26]. He believed that human ability is limited but human capital can infinitely cause the development of firm. Pennings, Lee and Witteloostuijn also indicated that organizational human capital (professional education) curtails the probability of firm's dissolution [27]. If this to be true, the firm is a place that different specialties of labor force combine together which result the creation of new and knowledge-based products. Therefore, firms employ both tangible resources (such as buildings and financial resources) and intangible resources (like human capital) in the development and implementation of strategies [28]. However, it seems that value-creating assets of a service firm rest more on its human capital than on its physical infrastructures [29].

Innovation is one of the performance aspects of firm that is a main determinant in finding new markets and reaching to more sales. In viewpoint of Schultz [30], the assumption is that education-even at primary level-increases the individual's ability in understanding new problems, illumination of these problems and finding the ways to solve them. Perhaps on the basis of this reason, Feldman [31] assumed that very much educated individuals make more innovations. This claim is quite straightforward and logical. The individual by schooling and getting more awareness learns to propose new options for quitting any bottleneck and making any change. For example, consultant and designer managers in a corporation can create new products and, thereby, precede rivals in the market. In this line, Andersson and Ejermo [32] studied the performance of 130 Swedish companies with regard to innovation. They found that there is a positive relationship between the innovativeness of a corporation and its accessibility to university researchers. Accordingly, the more a firm employs specialist labor force, the more improvement in competitive advantage in the market.

This issue is visualized in export performance of a firm because export means going beyond national economy and presence in new markets to sell more products. Undoubtedly, in very intense international competition for capturing markets, the producer would be successful that earns more competitive advantage. Hence, it seems that firms innovate more can better expand their exports. Greenhalgh et al. [33] by examining the effect of innovation on Britain's export observed that innovation has positive impact on export volume in most industries. Wakelin [34] also investigated the role of innovation in export behavior of British firms. The main finding of her research is that the number of past innovations has a positive impact on the probability of an innovative firm exporting. 
Roper and Love [35] studied the determinants of export performance among the UK and German manufacturing plants. They showed that product innovation has a strong effect on the probability and propensity to export in both countries. Being innovative is positively related to export probability in both countries. Since exporter firms are more subject to technological advances and changes in markets, they utilize the human capital more efficiently than other parts of economy. The reason is that educated workers can adapt themselves more rapidly with sophisticated technologies and with fast changes of production which is requisite for competitiveness in world markets [36]. In addition, internalization of human capital may enhance a firm's core capabilities and lower transaction costs; it also accrues managerial and bureaucratic costs [37].

These discussions indicate that the higher the level of managers' and workers' education, the more successful firm in export performance. Various researches confirm this idea [29] [35] [36] [51] [52] [53] [54] [55]. The most researchers analyzed the effect of education on export on the basis of production function approach while it is directly introduced the export function in current paper to estimate the impact of education.

Many researchers have examined the factors of export while only some of them have attempted to enter educational variables into their empirical analyses. At this point, some selected recent studies that have been done in terms of determinants of export are reported in Table 1 in summary. As is observed in Table 1, most studies have not covered the role of education. Only Rodríguez-Pose et al. [46] and Henn et al. [45] paid attention to education but the used measure for education was a single one that didn't include the details of educational situations. There is a lack of evidence focusing on the role of education whilst current study seeks to resolve this deficiency.

\section{Empirical Model and Data}

According to the represented arguments and hypothesis, we expect that export sector utilizes more educated human force which this feature contribute to the expansion of mentioned sector. But it is a wisely guess that particularly in a developing economy like Iran cannot be necessarily trusted because export in a such economy is not based on sophisticated and produced by knowledge of high-tech products. In this situation, it is possible that using educated employees leads weakly to growth of export. Therefore, we inevitably must test this claim. Accordingly, the export function proposed by Branson [11] is used as the basis of empirical analysis. This function represents export volume $(X)$ as a (negatively) function of both exchange rate $^{1}(E R)$ and domestic prices $(P)$. This is the simplest function of export.

$$
X=X(E R, P)
$$

The theoretical background of this model is the so called "demand theory" in

${ }^{1}$ Exchange rate has measured by domestic currency per foreign currency. 
Table 1. Summary of some recent relevant studies.

\begin{tabular}{cccc}
\hline Authors & Sample & Explanatory Variables & Results \\
\hline
\end{tabular}

Import from Japan by 30 largest export

partner countries; GDP per capita; Degree of Japan exports to countries with higher political

Yang et al. [38] Japan: 1994-2014

Kadochnikov \&

Fedyunina [39]

Russia: 2002-2010

Rodil et al. [40]

213 firms located in Galicia (north-west region of Spain): 2004-2005 the economic integration; Political risk of Japan's largest exports partner countries; Outward FDI from Japan to its 30 largest exports partner countries.

Human and financial resource characteristics Gravity variables and product characteristics; Product heterogeneity; Industry, Destination and year dummies.

Innovation variables; Structural

characteristics (size and sector).

Human resources

Navarro-García et al. [41] 196 Spanish exporting firms: 2012

(number of employees and managers);

Competitive intensity in foreign markets;

Export commitment; Marketing mix strategic decisions.

299 exporting firms in fast growing South American

Pino et al. [42] emerging economies

Type of firm; Localization of firm; Size (number of employees); Age of firm; Foreign (Colombia, Peru, and Chile): investment; Sector; Legal status of the firm. 2013-2014

Suárez-Porto \& Spanish manufacturing

Guisado-González [43] businesses: 2005

Skosan \& Kabuya [44] Swaziland: 1980-2010

Henn et al. [45]

178 Countries: 1962-2010

Rodríguez-Pose et al. [46]

Indonesian manufacturing firms: 1990-2005

Adeoti [47]

96 firms in Southwest Nigeria employing 20 or more persons

Abbasi et al. [48]
Iranian industries: 1995-2007
Product innovation; Process innovation; Sectorial technological intensity; Business extent; Membership to a pool of businesses.

FDI; Exchange rate; World demand; Domestic consumption; Real GDP.

Initial product quality level; Initial income per capita; Initial institutional quality; Initial human capital (secondary-school completion rate).

Firm specific characteristics; First-and second-nature geography characteristics; Regional factors

(measured by education as average years of schooling of the adult population).

Investment in ICT; Skills intensity ratio; Investment in skills upgrading; Investment in technology hardware; Technological collaboration with foreign firm(s); Investmentwith export potential, and it is the most imporin quality management; Firm size; Age of tant factor.

firm; Age in exporting; Destination of exporting; Ownership structure.

Import; Labour/capital ratio; Market structure; R \& D expenditures; Exchange rate; All explanatory variables have positive and Skilled labor.

The product innovation and the process Firm size has a strong positive relationship

stability, higher degree of economic integration with Japan and to countries which have larger outward foreign direct investment from Japan.

A better availability of human and financial resources improves export survival across Russian regions.

There is a positive relationship between innovation and exporting and that some factors (particularly, variety of innovation and marketing innovation) are critical.

Positive relationship between human resources-employees and managers-working on export activity and export commitment.

Organizational innovations (new or improved organizational methods) have more influence on market performance than marketing innovations. innovation influence in a positive and significant way the exporting intensity.

FDI, world demand, and nominal exchange rate are key significant factors in determining the export performance.

Increases in institutional quality and human capital are associated with faster quality upgrading.

Agglomeration effects, education, and transport infrastructure endowment play a particularly relevant role in export propensity. All explanatory vari
significant effect. 


\section{Continued}

\begin{tabular}{|c|c|c|c|}
\hline Carneiro et al. [49] & $\begin{array}{l}448 \text { large Brazilian } \\
\text { exporters of } \\
\text { manufactured products. }\end{array}$ & $\begin{array}{l}\text { Psychic distance; Business distance; Barriers } \\
\text { in the host country; Status of the exporting } \\
\text { activity; Systematization of export planning. }\end{array}$ & $\begin{array}{l}\text { Export performance exhibited a } \\
\text { multidimensional structure and the model } \\
\text { explained } 76.6 \% \text { and } 40.1 \% \text { of the observed } \\
\text { variance of past export revenues and of past } \\
\text { export profitability, respectively. }\end{array}$ \\
\hline $\begin{array}{l}\text { Mohammadzadeh anc } \\
\text { Sojoodi [50] }\end{array}$ & $\begin{array}{l}12301 \text { Iranian industrial } \\
\text { firms: } 2007\end{array}$ & $\begin{array}{l}\text { R \& D expenditures; Ownership of firm; } \\
\text { Capital/Labour ratio; Human capital } \\
\text { (BA or BS labours or higher); Wage. }\end{array}$ & $\begin{array}{l}\text { Human capital and ownership have no effect } \\
\text { on export. Greater capital/labour ratio } \\
\text { leads to more export. }\end{array}$ \\
\hline
\end{tabular}

microeconomics. The core of this theory is that following an increase in price, the demand for goods rises. Consequently, as the domestic prices go up the domestically produced goods become high-priced which means that these goods are more expensive in international markets now. Therefore, the demand for domestic goods by foreign consumers decrease and exports lessen then. In addition, according to Branson's theoretical framework [11], as exchange rate goes down the national currency depreciates and hence domestic producers who attend in foreign markets are motivated to export more because they can earn more national currency from export now. This idea is also based on demand theory because exchange rate determines the purchasing power of foreign consumers in terms of goods. As exchange rate rises, the purchasing power of foreign consumers increase and their demand ascend.

Carlin and Soskice [56] also inserted a measure of competitiveness into the export equation. In this line, the degree of competition in industry affects export performance of firms too thereby that the more competitive market structure, the more export takes place [57] [58]. Moreover, on the basis of human capital and firm theory, education of employees (labors and managers) also influences export. On the whole, the generalized form of Equation (1) is defined as follows:

$$
X=X(E R, I N F, C O M, I N V, \overrightarrow{E C}, R D, \overrightarrow{E D U})
$$

Equation (2) constitutes the empirical model in current studywhile the error term is dealt with in the regression. Table 2 includes the introduction and definition of variables which are used in estimations.

It is noted that domestic price level is replaced by inflation rate. The expectation is that high inflation impedes the growth of export. Investment is also a control for export because more investment enhances firm's capability to enter to world markets. In addition, since the study is confined to industry sector and Iran's economy is identified by affluence of energy resources which facilitates gaining them for industrial producers, ${ }^{2}$ the quantity of energy inputs potentially have effect on export volume. Consequently, a vector of energy conveyors has been placed in Equation (2). Besides, R \& D expenditures may be an influence factor of export which is employed in model.

Vector of education consists of variables which of them refer to a level of education or sum of some levels. Educational levels are primary to $\mathrm{PhD}$. In order

${ }^{2}$ The government in Iran even provides subsidies for energy which this attempt makes access to energy to be easier and cheaper. 
Table 2. Description of variables.

\begin{tabular}{|c|c|}
\hline Variable & Description \\
\hline Export (X) & The value of export; deflated by the export price index. \\
\hline Exchange rate (ER) & US Dollar per Rial. \\
\hline Inflation (INF) & Percentage growth of CPI. \\
\hline Competition (COM) & The number of firms in any industry. \\
\hline Investment (INV) & $\begin{array}{l}\text { The value of investment in industry; measured by division } \\
\text { of the value of fixed capital formation in producer } \\
\text { price index. }\end{array}$ \\
\hline \multicolumn{2}{|l|}{ Vector of energy conveyors (EC): } \\
\hline Fuel (FU) & $\begin{array}{l}\text { The volume of liquid fuels including gasoline, diesel oil, } \\
\text { kerosene, petroleum and furnace oil. }\end{array}$ \\
\hline Electricity (EL) & The quantity of consumed electricity. \\
\hline Gas (G) & The volume of natural gas, consumed by industries. \\
\hline $\mathrm{R} \& \mathrm{D}(\mathrm{RD})$ & The expenditures on research and development. \\
\hline \multicolumn{2}{|l|}{ Vector of education (EDU): } \\
\hline Under-secondary schooling (UDIP) & $\begin{array}{l}\text { The ratio of the number of productive employees who } \\
\text { their years of schooling are less than } 12 \text { to the whole } \\
\text { of productive employees. }\end{array}$ \\
\hline Secondary schooling (DIP) & $\begin{array}{l}\text { The ratio of the number of productive employees who } \\
\text { completed secondary education to the whole of } \\
\text { productive employees.. }\end{array}$ \\
\hline Education in school (SE) & The sum of UDIP and DIP. \\
\hline Two years college (TC) & $\begin{array}{l}\text { The ratio of the number of productive employees with } \\
\text { two years education in university to the whole of } \\
\text { productive employees. }\end{array}$ \\
\hline Bachelor of Arts or Science (BA) & $\begin{array}{c}\text { The ratio of the number of productive employees who } \\
\text { have graduated in university with BA or BS to the } \\
\text { whole of productive employees. }\end{array}$ \\
\hline Master of Arts or Science (MA) & $\begin{array}{l}\text { The ratio of the number of productive employees who } \\
\text { have graduated in university with MA or MS to the } \\
\text { whole of productive employees. }\end{array}$ \\
\hline Doctor of Philosophy (PHD) & $\begin{array}{c}\text { The ratio of the number of productive employees who } \\
\text { have PhD degree to the whole of productive } \\
\text { employees. }\end{array}$ \\
\hline Higher education (HE) & The sum of TC, BA, MA and $\mathrm{PhD}$. \\
\hline
\end{tabular}

Source: Descriptions presented by author.

to compare education in school to university, 12 years of education or less with higher education are considered. Use of these two variables helps us to examine the importance of education at higher level as a whole and identify whether higher education excel lower level or not.

Data are restricted to Iranian industrial firms with 10 employees or more in 2003-2013. The reason of selecting the year 2013 as the end of period is that the data have not been accessible to extend the period to recent years. Thus, this is another limitation of research. Industries have been selected according to two-digit codes of ISIC. The data have been gathered from Statistical Center of Iran [59]. Iran is a developing country which oil constitutes the large portion of 
its export while has tried recent years to develop industry and non-oil export. Hence, presenting empirical evidence about export performance of industry sector in Iran, particularly with emphasis on role of education, can demonstrate some facts on the degree of success of policies-especially support to knowledge-based industries - which focus to industry.

\section{Results}

Our purpose is to estimate Equation (2) by using a panel data of Iranian industries. At first, Hausman test is done to recognize the method of estimation. The basic tested model in no logarithmic form showed that the Chi-square statistic is equal to 55.5 which is statistically significant at $1 \%$ level. Therefore, the fixed effect method is used to estimate regressions.

It is useful to examine the results of unit root test of variables prior to estimation of regressions. Table 3 presents these results. It is observed that all variables are stationary at level except exchange rate and electricity. Consequently, we can use the most variables without making difference but two recently mentioned variables. Equation (2) is estimated in various forms. All regressions have been specified as log-log because this manner gives us the elasticities. This approach helps us to compare the magnitude of impact of different levels of education on export. The results of estimations are presented in Table 4 and Table $5 .^{3}$

Table 3. Unit root test of variables at level by Levin, Lin \& Chu $t^{\star}$ method.

\begin{tabular}{ccc}
\hline Variable & Statistic & Result \\
\hline X & $-16.4^{*}$ & Stationary \\
ER & 46.2 & No stationary \\
INF & $-10.2^{*}$ & Stationary \\
COM & $-1.93^{* *}$ & Stationary \\
INV & $-2.2^{* *}$ & Stationary \\
FU & $-5.77^{*}$ & Stationary \\
EL & 4.9 & No stationary \\
G & $-3.99^{* *}$ & Stationary \\
RD & $-2.47^{*}$ & Stationary \\
UDIP & $-5.39^{*}$ & Stationary \\
DIP & $-8.8^{*}$ & Stationary \\
SE & $-7.78^{*}$ & Stationary \\
TC & $-5.33^{\star}$ & Stationary \\
BA & $-2.39^{*}$ & Stationary \\
MA & $-3.02^{*}$ & Stationary \\
PHD & NA & But stationary by (ADF-PP) Fisher \\
HE & $-2.81^{*}$ & chi-square \\
\hline & Stationary \\
\hline
\end{tabular}

Source. Findings accessed by author. Note: Numbers denoted by ${ }^{*}{ }^{* *}$ and ${ }^{* * *}$ in second column are significant at $1 \%, 5 \%$ and $10 \%$ respectively.

${ }^{3}$ The robustness check has been accomplished but does not present. 
Table 4. Determinants of export in Iranian industries (Panel EGLS coefficients).

\begin{tabular}{|c|c|c|c|c|}
\hline \multirow{2}{*}{ Regressors } & \multicolumn{4}{|c|}{ Regressions } \\
\hline & 1 & 2 & 3 & 4 \\
\hline Constant & $-5.1^{\star \star}(2.2)$ & $-1.1(0.4)$ & $-1.8(0.7)$ & $-0.97(0.4)$ \\
\hline $\mathrm{D}(\mathrm{ER})$ & $0.092^{*}(3.4)$ & $0.097^{*}(3.6)$ & $0.101^{\star}(3.9)$ & $0.097 *(3.99)$ \\
\hline INF & $-0.245^{\star}(3.1)$ & $-0.22^{\star *}(2.6)$ & $-0.218^{\star}(2.65)$ & $-0.21^{\star}(2.73)$ \\
\hline $\mathrm{COM}$ & $1.01^{\star}(3.4)$ & $0.511^{\star \star}(2.09)$ & $0.601^{\star}(3.18)$ & $0.491^{\star \star}(2.28)$ \\
\hline INV & $0.175^{\star \star}(2.1)$ & $0.186^{\star \star}(2.48)$ & $0.189^{* *}(2.6)$ & $0.185^{\star \star}(2.42)$ \\
\hline $\mathrm{D}(\mathrm{EL})$ & $-0.003(0.24)$ & $-0.008(0.49)$ & $-0.008(0.57)$ & $-0.005(0.43)$ \\
\hline G & $0.466^{\star}(3.1)$ & $0.313^{\star}(2.7)$ & $0.355^{\star \star}(2.45)$ & $0.316^{\star \star}(2.42)$ \\
\hline FU & $-0.09(1.2)$ & $-0.021(0.41)$ & $-0.017(0.35)$ & $-0.026(0.49)$ \\
\hline $\mathrm{RD}$ & $0.018(0.35)$ & & & \\
\hline UDIP & & $-0.243(0.82)$ & & \\
\hline DIP & & & $0.202(0.62)$ & \\
\hline SE & & & & $-0.719(1.51)$ \\
\hline Adjusted R-squared & 0.995 & 0.996 & 0.995 & 0.995 \\
\hline F-Statistic & $1034.3^{*}$ & $1146.1^{*}$ & $1100.4^{*}$ & $1136.1^{*}$ \\
\hline
\end{tabular}

Source: Findings of current research. Note: All variables are logarithmic. Numbers in parentheses at the right of coefficients are absolute value of t-statistics. ${ }^{*},{ }^{* *}$ and ${ }^{* * *}$ are significant at $1 \%, 5 \%$ and $10 \%$ respectively.

Table 5. Determinants of export in Iranian industries (Panel EGLS coefficients).

\begin{tabular}{|c|c|c|c|c|c|}
\hline \multirow[b]{2}{*}{ Regressors } & \multicolumn{5}{|c|}{ Regressions } \\
\hline & 1 & 2 & 3 & 4 & 5 \\
\hline Constant & $-2.3(0.84)$ & $-5.2^{\star \star \star}(1.8)$ & $0.25(0.08)$ & $-4.4^{*}(3.2)$ & $-2.9(1.03)$ \\
\hline $\mathrm{D}(\mathrm{ER})$ & $0.102^{\star}(3.93)$ & $0.115^{\star}(3.9)$ & $0.086^{\star}(3.34)$ & $0.13(1.19)$ & $0.102^{\star}(3.9)$ \\
\hline INF & $-0.238^{\star}(3.08)$ & $-0.143(1.65)$ & $-0.232^{*}(3.31)$ & $-0.03(0.26)$ & $-0.17^{\star \star}(2.15)$ \\
\hline $\mathrm{COM}$ & $0.663^{\star}(3.05)$ & $0.484^{\star \star}(2.1)$ & $0.532^{\star}(2.95)$ & $0.083(0.89)$ & $0.566^{* *}(2.45)$ \\
\hline INV & $0.18^{\star *}(2.38)$ & $0.239 *(3.94)$ & $0.162^{\star *}(2.14)$ & $0.532^{\star}(4.6)$ & $0.195^{\star}(2.69)$ \\
\hline $\mathrm{D}(\mathrm{EL})$ & $-0.004(0.35)$ & $0.015(0.89)$ & $-0.007(0.48)$ & & $-0.002(0.18)$ \\
\hline G & $0.37^{* *}(2.44)$ & $0.487^{\star}(3.51)$ & $0.303^{* * *}(1.92)$ & $0.548^{*}(5.1)$ & $0.426^{*}(2.94)$ \\
\hline $\mathrm{FU}$ & $-0.014(0.28)$ & $-0.034(0.66)$ & $-0.02(0.42)$ & $0.11(1.03)$ & $-0.03(0.68)$ \\
\hline TC & $0.126(0.8)$ & & & & \\
\hline BA & & $-0.736^{\star}(2.93)$ & & & \\
\hline MA & & & $0.185^{* * *}(1.68)$ & & \\
\hline PHD & & & & $0.152^{\star * *}(1.86)$ & \\
\hline $\mathrm{HE}$ & & & & & $-0.24(1.03)$ \\
\hline $\begin{array}{c}\text { Adjusted } \\
\text { R-squared }\end{array}$ & 0.995 & 0.996 & 0.995 & 0.76 & 0.995 \\
\hline F-Statistic & $1053.9^{\star}$ & $1304.4^{\star}$ & $991.9^{*}$ & $89.7^{\star}$ & $1108.04^{\star}$ \\
\hline
\end{tabular}

Source: Findings of current research. Note: All variables are logarithmic. Numbers in parentheses at the right of coefficients are absolute value of t-statistics. ${ }^{*},{ }^{* *}$ and ${ }^{* * *}$ are significant at $1 \%, 5 \%$ and $10 \%$ respectively. 
Table 4 represents the estimation of Equation (2) while the vector of education contains schooling less than tertiary, that is, 12 years of schooling or less. Regression 1 in Table 4 is benchmark model which does not include education. Regressions 2 and 3 indicate that completion of high school or lower schooling has no significant effect on industrial export. Regression 4 also shows that education lower than tertiary does not contribute to more export as a whole. This observation confirms that lower levels of education which take place in school is not an important factor of export. Table 4 also reveals, as expected, that exchange rate, investment, competition and gas have positive effect on export. The impact of inflation coincides to theory whereupon higher inflation leads to decrease of export. On the contrary, electricity, fuel and R \& D do not show significant effect.

In Table 5, former educational variables have been replaced by tertiary education. It is obvious that higher education has no significant effect in all regressions. None of educational levels in university influence the export of industries. However, the variable $\mathrm{HE}$ which includes the whole of employees who have graduated from university does not show any effect, which is in line with variable SE. Apparently, there is evident distinction between tertiary in one hand and primary and secondary in other hand. Two years college has no significant effect but BA or BS degree reveals the negative and statistically significant effect.

On the contrary, MA or MS and PhD degrees demonstrate the positive and significantly effects. That is, Iranian industries' export products need to high knowledge and specialty which means Iranian economy becomes more knowledge-based to produce goods based on knowledge and employ very high educated labor. Comparing the coefficients (elasticities) of these two variables sheds light on that MA (MS) degree has somewhat more strong effect than $\mathrm{PhD}$ degree. A one percent increase in $\mathrm{MA}(\mathrm{PhD})$ employees leads to 0.18 percent $(0.15$ percent) increase in export.

\section{Concluding Remarks}

This study has been organized in the line of human capital theory and knowledge-based economy literature to examine the issue whether education contributes to the growth of Iranian industries export, and if it is true, do different levels of education have different roles. The expectation was that the export of industry sector to be more dependent to high educated employees than to lower levels of education. Evidence suggests that employing educated employees leads to the growth of industrial export as human capital approach demonstrates. Therefore, literate labor is preferred to illiterate ones but the positive effect of education is credible only for the top levels of higher education. This means that higher levels of education have achievements for manufacturing. These findings reveal that industry approaches to knowledge-based economy in Iran and need to highly professional labor. Iranian industries export more processed products now which are produced by employing just literate labor armed with high spe- 
cialty. Consequently, it seems that education is a determinant of export in some but not all levels. Hence, perhaps it can be concluded that these results are somewhat in contrast to filter theory proposed by Arrow [60] in the sense that higher education has no effect on productivity. Accordingly, higher education is so capable to increase productivity of Iranian industries to be eligible to compete with rivals in world markets.

\section{References}

[1] World Bank (1993) The East Asian Miracle: Economic Growth and Public Policy. Oxford University Press, Oxford.

[2] Glewwe, P. and Kremer, M. (2006) Schools, Teachers, and Education Outcomes in Developing Countries. In: Hanushek, E.A. and Welch, F., Eds., Handbook of the Economics of Education, Vol. 2, North Holland Publishing Co, Amsterdam, 945-1017.

[3] Stokey, N.L. (1991) Human Capital, Product Quality and Growth. The Quarterly Journal of Economics, 106, 587-616. https://doi.org/10.2307/2937948

[4] Romer, P.M. (1986) Increasing Returns and Long-Run Growth. Journal of Political Economy, 94, 1002-1037. https://doi.org/10.1086/261420

[5] Lucas, R.E. (1988) On the Mechanics of Economic Development. Journal of Monetary Economics, 22, 3-42. https://doi.org/10.1016/0304-3932(88)90168-7

[6] Azariadis, C. and Drazen, A. (1990) Threshold Externalities in Economic Development. The Quarterly Journal of Economics, 105, 501-526.

https://doi.org/10.2307/2937797

[7] Romer, P.M. (1990) Human Capital and Growth: Theory and Evidence. Carnegie-Rochester Conference Series on Public Policy, 32, 251-286. https://doi.org/10.1016/0167-2231(90)90028-J

[8] Benhabib, J. and Spiegel, M.M. (1994) The Role of Human Capital in Economic Development: Evidence from Aggregate Cross-Country Data. Journal of Monetary Economics, 34, 143-173. https://doi.org/10.1016/0304-3932(94)90047-7

[9] Fleisher, B.M., Hu, Y., Li, H. and Kim, S. (2011) Economic Transition, Higher Education and Worker Productivity in China. Journal of Development Economics, 94, 86-94. https://doi.org/10.1016/j.jdeveco.2010.01.001

[10] Bils, M. and Klenow, P.J. (1998) Does Schooling Cause Growth or the Other Way Around? NBER Working Paper No. 6393.

[11] Branson, W.H. (1989) Macroeconomic Theory and Policy. Harper \& Row, New York.

[12] Schultz, T.W. (1961) Investment in Human Capital. American Economic Review, 51, 1-17.

[13] Becker, G.S. (1962) Investment in Human Capital: A Theoretical Analysis. Journal of Political Economy, 70, 9-49. https://doi.org/10.1086/258724

[14] Jones, P. (2001) Are Educated Workers Really More Productive? Journal of Development Economics, 64, 57-79.

[15] Nelson, R.R., and Phelps, E.S. (1966) Investment in Humans, Technological Diffusion, and Economic Growth. The American Economic Review, 56, 69-75.

[16] Thomas, D., Strauss, J. and Henriques, M.H. (1991) How Does Mother's Education Affect Child Height? The Journal of Human Resources, 26, 183-211. 
[17] Becker, G.S. (1993) Human Capital: A Theoretical and Empirical Analysis, with Special Reference to Education. The University of Chicago Press, Chicago and London.

[18] Huffman, W.E. (1977) Allocative Efficiency: The Role of Human Capital. The Quarterly Journal of Economics, 91, 59-79. https://doi.org/10.2307/1883138

[19] Ali, S.A., Ahmed, Q.M. and Naz, L. (2016) Public Spending on Human Capital Formation and Economic Growth in Pakistan. Asia-Pacific Development Journal, 23, 1-20.

[20] Behrman, J.R. (1994) The Contribution of Human Capital to Economic Development: Some Selected Issues. International Labour Office, Working Paper No. 36.

[21] Arrow, K.J. (1962) The Economic Implications of Learning by Doing. The Review of Economic Studies, 29, 155-173. https://doi.org/10.2307/2295952

[22] Feldman, M.P. (1999) The New Economics of Innovation, Spillovers and Agglomeration: A Review of Empirical Studies. Economics of Innovation and New Technology, 8, 5-25. https://doi.org/10.1080/10438599900000002

[23] Sepúlveda, F. (2010) Training and Productivity: Evidence for US Manufacturing Industries. Oxford Economic Papers, 62, 504-528. https://doi.org/10.1093/oep/gpp028

[24] Grant, R.M. (1996) Toward a Knowledge-Based Theory of the Firm. Strategic Management Journal, 17, 109-122. https://doi.org/10.1002/smj.4250171110

[25] Spender, J.C. (1996) Making Knowledge the Basis of a Dynamic Theory of the Firm. Strategic Management Journal, 17, 45-62. https://doi.org/10.1002/smj.4250171106

[26] Otani, K. (1996) A Human Capital Approach to Entrepreneurial Capacity. Economica, 63, 273-289.

[27] Pennings, J.M., Lee, K. and Witteloostuijn, A.V. (1998) Human Capital, Social Capital, and Firm Dissolution. The Academy of Management Journal, 41, 425-440.

[28] Hitt, M.A., Bierman, L., Shimizu, K. and Kochhar, R. (2001) Direct and Moderating Effects of Human Capital on Strategy and Performance in Professional Service Firms: A Resource-Based Perspective. The Academy of Management Journal, 44, 13-28.

[29] Bouquet, C., Hebert, L. and Delios, A. (2004) Foreign Expansion in Service Industries: Separability and Human Capital Intensity. Journal of Business Research, 57, 35-46. https://doi.org/10.1016/S0148-2963(02)00282-5

[30] Schultz, T.W. (1975) The Value of the Ability to Deal with Disequilibria. Journal of Economic Literature, 13, 827-846.

[31] Feldman, M.P. (2000) Location and Innovation: The New Economic Geography of Innovation, Spillovers, and Agglomeration. The Oxford Handbook of Economic Geography. Oxford University Press, Oxford.

[32] Andersson, M. and Ejermo, O. (2005) How Does Accessibility to Knowledge Sources Affect the Innovativeness of Corporations? Evidence from Sweden. The Annals of Regional Science, 39, 741-765. https://doi.org/10.1007/s00168-005-0025-7

[33] Greenhalgh, C., Taylor, P. and Wilson, R. (1994) Innovation and Export Volumes and Prices: A Disaggregated Study. Oxford Economic Papers, New Series, 46, 102-135. https://doi.org/10.1093/oxfordjournals.oep.a042115

[34] Wakelin, K. (1998) Innovation and Export Behaviour at the Firm Level. Research Policy, 26, 829-841. https://doi.org/10.1016/S0048-7333(97)00051-6

[35] Roper, S. and Love, J.H. (2002) Innovation and Export Performance: Evidence from 
the UK and German Manufacturing Plants. Research Policy, 31, 1087-1102. https://doi.org/10.1016/S0048-7333(01)00175-5

[36] Levin, A. and Raut, L.K. (1997) Complementarities between Exports and Human Capital in Economic Growth: Evidence from the Semi-Industrialized Countries. Economic Development and Cultural Change, 46, 155-174. https://doi.org/10.1086/452325

[37] Lepak, D.P. and Snell, S.A. (1999) The Human Resource Architecture: Toward a Theory of Human Capital Allocation and Development. The Academy of Management Review, 24, 31-48. https://doi.org/10.5465/amr.1999.1580439

[38] Yang, W., Liu, Y.C. and Mai, C.C. (2017) How Did Japanese Exports Evolve from 1995 to 2014? A Spatial Econometric Perspective. Japan and the World Economy, 41, 50-58. https://doi.org/10.1016/j.japwor.2016.12.002

[39] Kadochnikov, S.M. and Fedyunina, A.A. (2017) The Impact of Financial and Human Resources on the Export Performance of Russian Firms. Economic Systems, 41, 41-51. https://doi.org/10.1016/j.ecosys.2016.11.001

[40] Rodil, Ó., Vence, X. and Sánchez, M.D.C. (2016) The Relationship between Innovation and Export Behaviour: The Case of Galician Firms. Technological Forecasting \& Social Change, 113, 248-265. https://doi.org/10.1016/j.techfore.2015.09.002

[41] Navarro-García, A., Arenas-Gaitán, J., Rondán-Cataluña, F.J. and Rey-Moreno, M. (2016) Global Model of Export Performance: Moderator Role of Export Department. Journal of Business Research, 69, 1880-1886. https://doi.org/10.1016/j.jbusres.2015.10.073

[42] Pino, C., Felzensztein, C., Zwerg-Villegas, A.M. and Arias-Bolzmann, L. (2016) Non-Technological Innovations: Market Performance of Exporting Firms in South America. Journal of Business Research, 69, 4385-4393. https://doi.org/10.1016/j.jbusres.2016.03.061

[43] Suárez-Porto, V. and Guisado-González, M. (2014) Analysis of the Determinants of Exporting Intensity in the Field of Innovation. Investigaciones Europeas de Dirección y Economía de la Empresa, 20, 79-86.

https://doi.org/10.1016/j.iedee.2013.12.002

[44] Skosan, S.V. and Kabuya, F.I. (2014) An Empirical Analysis of Determinants of Swaziland's Export Performance. International Journal of Sciences. Basic and Applied Research, 16, 197-212.

[45] Henn, C., Papageorgiou, C. and Spatafora, N. (2013) Export Quality in Developing Countries. IMF Working Paper, WP/13/108. https://doi.org/10.5089/9781484351635.001

[46] Rodríguez-Pose, A., Tselios, V., Winkler, D. and Farole, T. (2013) Geography and the Determinants of Firm Exports in Indonesia. World Development, 44, 225-240. https://doi.org/10.1016/j.worlddev.2012.12.002

[47] Adeoti, J.O. (2012) Technology-Related Factors as Determinants of Export Potential of Nigerian Manufacturing Firms. Structural Change and Economic Dynamics, 23, 487-503. https://doi.org/10.1016/j.strueco.2011.05.001

[48] Abbasi, G., Mirzaienezhad, M.R. and Donyabin, F. (2012) Influencing Factors on Industrial Export in Iran with Emphasis on Market Structure. The Journal of Planning and Budgeting, 17, 97-114. (In Persian)

[49] Carneiro, J., da Rocha, A. and da Silva, J.F. (2011) Determinants of Export Performance: A Study of Large Brazilian Manufacturing Firms. Brazilian Administration Review, 8, 107-132. https://doi.org/10.1590/S1807-76922011000200002 
[50] Mohammadzadeh, P. and Sojoodi, S. (2011) The Determinants of Export Performance in Manufacturing Firms of Iran. Journal of Executive Management, 3, 127-152. (In Persian)

[51] Busse, M. (2002) Do Labor Standards Affect Comparative Advantage in Developing Countries? World Development, 30, 1921-1932.

[52] Chuang, Y. (2000) Human Capital, Exports, and Economic Growth: A Causality Analysis for Taiwan, 1952-1995. Review of International Economics, 8, 712-720. https://doi.org/10.1111/1467-9396.00252

[53] Contractor, F.J. and Mudambi, S.M. (2008) The Influence of Human Capital Investment on the Exports of Services and Goods: An Analysis of the Top 25 Services Outsourcing Countries. Management International Review, 48, 433-445. https://doi.org/10.1007/s11575-008-0025-9

[54] Gråsjö, U. (2005) Human Capital, R \& D and Regional Export Performance. Centre of Excellence for Science and Innovation Studies. Electronic Working Paper Series, Paper No. 50.

[55] Kucera, D. and Sarna, R. (2005) Child Labour, Education and Export Performance. International Labour Organization, Working Paper No. 52.

[56] Carlin, W. and Soskice, D. (2006) Macroeconomics: Imperfections, Institutions and Policies. Oxford University Press, New York.

[57] Kim, D. and Marion, B.W. (1996) Measuring Effects of Domestic Market Structure on Trade Performance: an Application of Error Correction Model to the U.S. Beer Industry. Working Paper 113.

[58] Poddar, T. (2004) Domestic Competition Spurs Exports: The Indian Example. International Monetary Fund, WP/04/173.

https://doi.org/10.5089/9781451858662.001

[59] Statistical Center of Iran (2016) Census of Industrial Firms with 10 Employees and More. http://www.amar.org.ir

[60] Arrow, K.J. (1973) Higher Education as a Filter. Journal of Public Economics, 2, 193-216. https://doi.org/10.1016/0047-2727(73)90013-3 